\title{
Pengembangan Ekonomi Kreatif Kerajinan Sutera di Kabupaten Wajo
}

\author{
Helda Ibrahim ${ }^{1}$, Majdah M. Zain², Suardi Bakri³, Awaluddin Yunus ${ }^{4}$, Tamzil Ibrahim ${ }^{5}$ \\ 1,2,3,4,5Fakultas Pertanian,Universitas Islam Makassar
}

\begin{abstract}
Silk development in Wajo Regency is relatively strategic since it involves farmers, opens business opportunities, gives an opportunity for populist economic development, and increases farmer's income and foreign exchange. Wajo Regency is known as silk producer city in South Sulawesi. Silk weaving activity has been the daily activity of Sengkang Bugis people since their ancestors. The research purposes were (1) to what extent is the characteristic of silk craftsmen in silk craft development conducted in Tanasitolo Sub-district Wajo Regency; and (2) how is silk product development in Tanasitolo Sub-district Wajo Regency. The research was conducted at Pakkana Village Tanasitolo Sub-district Wajo Regency with consideration that the area is one of centers for silk product business development in Wajo Regency. Samples taken were 30 people using purposive sampling. The research results indicate that the characteristics of silk craftsmen in Tanah Sitolo area of Wajo Regency were: 1) Respondents in Pakkanna Village were all female; (2) the highest respondent age (80\%) was between $26-50$ years old; $13.33 \%$ were under 25 years old and $6.67 \%$ were above 50 years old; (3) respondent's family dependents were mostly 5-6 people, which was 36.67 percent; (4) based on experience, most respondents has the longest experiences of 20-25 years, which was 13 percent; and (5) most respondents (50\%) had average level of education of junior high school (SMP). Silk craft development had been long conducted but it was in the level of design motive renewal packed with modern motive according to merchants' order level and consumers' direct order. The development has been a creative economic-based development.
\end{abstract}

Keywords: development, creative economy, silk, craftsmen

\section{PENDAHULUAN}

Indonesia dengan potensi kekayaan yang sangat besar baik potensi sumber daya alam, keragaman budaya maupun sumber daya manusia perlu mengedepankan kreativitas dan inovasi dalam pembangunan nasional untuk mengoptimalkan berbagai potensi kekayaan yang dimilikinya. Ekonomi kreatif yang berbasis kepada modal kreativitas sumber daya manusia, berpeluang mendorong daya saing bangsa Indonesia di masa depan. Jika sumber daya manusia Indonesia yang jumlahnya sangat besar memiliki kemampuan untuk berkreasi untuk menciptakan inovasi dan nilai tambah, maka kreativitas tersebut akan menjadi sumberdaya terbarukan yang tidak ada habisnya.

Kerajinan sutera sebagai bagian dari sub sektor industri kreatif merupakan salah satu jenis usaha yang sangat berkembang di Indonesia pada saat ini. Munculnya beraneka jenis produk yang unik, dengan desain yang bagus bernuansa kearifan lokal menjadi bukti bahwa usaha ini berkembang cukup pesat. Pertenunan sebagai salah satu output dari subsistem pengolahan hasil produk tenun yang merupakan salah satu subsistem dalam agribisnis sangat strategis untuk dikembangkan karena dapat memberi nilai tambah dan pendapatan serta kesejahteraan masyarakat khususnya petani kokon dan pelaku usaha agribisnis. Usaha tenun yang berkembang pesat secara tidak langsung dapat memberi nilai tambah pada produk industri kecil dan berpengaruh pada tingginya permintaan bahan baku.

Sulawesi Selatan sebagai salah satu Provinsi terbesar di Kawasan Timur Indonesia memiliki beraneka produk sutera yang berbeda-beda tergantung pada daerah penghasil produk sutera di setiap daerahnya. Potensi produk kerajinan sutera dengan nilai ekonomi kreatif dapat menjadi sebuah jalan atau jawaban untuk meningkatkan peluang usaha produk sutera di Sulawesi Selatan khususnya melalui pengembangan dan pemasaran produk berbasis ekonomi kreatif. 
Oleh karena itu sangat penting diketahui 1) Sejauh mana karakteristik pengrajin sutera dalam pengembangan kerajinan sutera yang sudah dilakukan di kecamatan Tanasitolo Kabupaten Wajo. 2) Bagaimana pengembangan produk sutera di Kecamatan Tanasitolo Kabupaten Wajo. Adapun tujuan kegiatan ini adalah untuk menganalisis karakteristik pengrajin sutera dalam pengembangan kerajinan sutera yang sudah dilakukan di Kecamatan Tanasitolo Kabupaten Wajo.

\section{METODE PENELITIAN}

Penelitian ini dilaksanakan di Desa Pakkanna Kecamatan Tanasitolo Kabupaten Wajo, mempertimbangkan bahwa daerah tersebut merupakan salah satu daerah sentra pengembangan usaha produk sutera di Kabupaten Wajo. Adapun sampel yang diambil sebanyak 45 orang dengan cara purposive sampling.

\section{HASIL DAN PEMBAHASAN}

\section{A. Karakteristik Responden}

Karakteristik responden pengrajin sutera yakni (1) Jenis kelamin responden di desa Pakkanna semua wanita (2) usia responden antara 26-50 tahun menempati urutan tertinggi yakni $80 \%$, di bawah 25 tahun sebanyak $13,33 \%$ dan diatas 50 tahun yakni 6,67\%; (3) tanggungan keluarga yang terbanyak memiliki yaitu tanggungan sebanyak 5-6 orang yaitu $36,67 \%$, (4) dari segi pengalaman responden, maka yang mempuyai pengalaman terbanyak yakni 20-25 tahun yaitu 13\%, dan (5) untuk tingkat pendidikan, rata-rata tingkat pendidikan sekolah menengah pertama (SMP) yaitu $50 \%$.

Asumsi yang dapat ditarik dari pemaparan tersebut adalah bahwa jika salah satu indikator peningkatan penyerapan tenaga kerja adalah faktor usia pekerja maka kemungkinan penyerapan tenaga kerja akan meningkat. Makin muda menenun biasanya mempunyai semangat untuk ingin tahu apa yang belum mereka ketahui, sehingga dengan demikian mereka berusaha untuk lebih cepat melakukan adopsi inovasi baru walaupun sebenarnya mereka belum berpengalaman menenun.
Tanggungan keluarga merupakan sumberdaya manusia yang dimiliki oleh penenun, terutama yang masih berusia produktif dan yang iku membantu dalam menenun, dari 30 responden mayoritas jumlah tanggungan terbanyak berada pada 3-4 orang dan responden sebanyak 15 responden. Jumlah anggota keluarga juga mempengaruhi keadaan perekonomian rumah tangga.

Rumah tangga yang memiliki jumlah anggota keluarga banyak, mayoritas dalam rumah tangga tersebut dituntut untuk memperoleh pendapatan yang relatif besar untuk memenuhi kebutuhan keluarga.Jumlah anggota keluarga yang banyak juga dapat membantu perekonomian keluarga. Semakin banyak jumlah tanggungan keluarga maka peluang untuk menenun semakin tinggi karena adanya tuntutan yang semakin tinggi untuk mensejahterakan anggota keluarganya.

Pengalaman menenun merupakan salah satu unsur yang menunjang peningkatan produktivtas masyarakat. Dengan pendidikan serta ditunjang dengan pengalaman yang cukup, maka seorang akan lebih kreatif dalam menenun. Pengalaman menenun dapat dilihat dari lamanya seseorang melakukan kegiatan menenun semakin lama seseorang bekerja pada kegiatan tersebut maka semakin banyak pengalaman yang diperolehnya. Pengalaman menenun merupakan salah satu faktor utama bagi penentu sumber daya manusia yang mempengaruhi tingkat pengelolaan pertenunan, dimana semakin lama seseorang bekerja pada suatu bidangnya maka semakin tinggi pengalaman kerja dalam bidangnya. Hal mempengaruhi tingkat keberhasilan menenun sebab dari pengalaman yang dimilikinya. Seorang responden dapat menentukan langkah atau tindakan selanjutnya untuk dapat memperoleh pendapatan usaha yang lebih besar. Pengalaman penenun Desa Pakkanna responden cukup bervariasi, yakni 7-10 tahun sebanyak 5 responden, 11-20 tahun sebanyak 21 orang responden, 20-25 sebanyak 4 responden dan sudah punya pengalaman membuat beberapa jenis motif tenun antara lain motif Balo Are, Balo Renni, Balo Lobang, Cora Subbi Lobang, pucuk si kadang, Balo Tettong, Ma'lobang, Lagosi, Pucuk, Songket 
Biasa, Songket Mahal, Sobbi, Sutera Samarinda, dll.

Tingkat pendidikan akan berkaitan dengan pola pikir Pekerja. Namun demikian untuk kegiatan usaha tenun tidak berdampak sangat signifikan, hal ini berkaitan baik yang sifatnya langsung maupun tidak langsung terhadap jenis usaha yang mereka lakukan dimana, kapan, dan oleh siapa pun karena bisa bekerja. Tingkat pendidikan sendiri baru akan terlihat pada sistem manajemen pengolahan produk kerajinan sutera yang mereka lakukan diikuti dengan pengalaman usaha yang mereka dapatkan.

\section{B. Pengembangan Ekonomi Kreatif Kerajinan Sutera}

Pada Klasifikasi Industri Kreatif Menurut United Nations Conference on Trade and Development (UNCTAD) menggolongkan kerajinan sutera termasuk dalam kategori heritage, karena memiliki ekspresi budaya tradisional. Kerajinan sutera ini merupakan kerajinan yang sudah diusahakan oleh masyarakat Kabupaten Wajo secara turun temurun.

Kebudayaan adalah sesuatu yang bersifat dinamis. Nilai sosial budaya membentuk suatu keyakinan yang menjadi pedoman dalam perjalanan hidup manusia. Etnis Bugis Makassar selalu mendefenisikan diri mereka berdasarkan kerajaan-kerajaan Bugis yang pernah ada di Sulawesi Selatan seperti Kerajaan Gowa, Luwu, Bone, Soppeng, Wajo dan Sidenreng. Kebudayaan Bugis Makassar menunjuk pada suatu tradisi yang hidup dibeberapa kabupaten di Sulawesi Selatan.

Terjadinya perubahan dalam kebudayaan Bugis disebabkan karena adanya kontak dengan kebudayaan dari luar seperti antara kebudayaan Bugis dengan bangsa-bangsa Eropa, Amerika, Asia dan Australia. Peran agen perubahan (agen of change) sangat menentukan dalam proses perubahan kebudayaan. Agen perubahan yang turut memberikan andil terjadinya perubahan pada kebudayaan Bugis yaitu ulama, pedagang, kerajaan (para raja-raja dan bangsawan) negara atau pemerintah, media dan mausia Bugis Makassar itu sendiri. Jika diperhatikan kondisi pertenunan yang ada di Provinsi Sulawesi Selatan umumnya merupakan usaha kecil dengan penggunaan peralatan tenun berupa gedokan dan ATBM. Hal yang perlu mendapat perhatian dari lembaga-lembaga yang terkait guna meningkatkan produksi seni kerajinan tenun sutera yang berkualitas seperti kain sutera untuk keperluan tertentu misalnya keperluan pakaian adat. Selain berbagai perubahan bentuk maka pergeseran makna yang mencolok yang dapat dilihat akhir-akhir ini adalah perubahan penggunaan dan pemakaian tenun sutera wajo seperti perbaikan bentuk dan penggunaannya yang pada awalnya hanya merupakan tenunan sarung dan baju bodo namun sekarang telah berubah dengan berbagai kegunaan seperti baju, jas bluiser, dasi, kipas sutra, tempat lipstik, tempat pensil, dompet dan tas pesta. Perubahan dan pergeseran berfungsi seperti itu pada umumnya dibuat demi memenuhi permintaan pasar yang juga diharapkan dapat meningkatkan pendapatan dari pertenunan sutera.

Di Provinsi Sulawesi Selatan terdapat beraneka ragam tenunan, hasil karya tenunan tersebut menunjukkan bahwa masyarakat Sulawesi Selatan memiliki pengalaman historis serta penguasaan pengetahuan dan teknologi yang telah tumbuh dan berkembang. Aktivitas menenun menggunakan peralatan dari kayu yaitu "Gedokan" orang Bugis menyebutnya "Ewangeng Tennung" dalam bahasa makassar disebut Pa"tanning. Proses menenun hingga kini tidak banyak mengalami perubahan kecuali pada bahan baku dan ragam hias yang berkembang. Jenis tenunan Bugis yang dikenal di Kabupaten Wajo yang cukup terkenal dan mengharumkan nama kota sengkang adalah sarung sutera (Lipa'sabbe to sengkang).

Kabupaten Wajo cukup potensial sebagai daerah penghasil kerajinan sutera, memiliki cukup banyak jenis usaha sentra pertenunan Gedongan dan Alat Tenun Bukan Mesin (ATBM). Di daerah ini terdapat sekitar 4.982 orang pengrajin gedongan dan 835 orang pengrajin ATBM dengan tenaga kerja 875 orang yang tersebar di semua kecamatan yang ada di Kabupaten Wajo. Produksi sekitar $1.589 .000 \mathrm{~m}$ kain sutera per tahun. Untuk sentra pemintal benang sutera sebanyak 98 orang dengan tenaga kerja sebanyak 289 orang yang tersebar pada beberapa kecamatan di Kabupaten Wajo. Kepala keluarga yang bergerak di bidang penanam- 
an murbei dan pemeliharaan ulat sutera sebanyak 301 kepala keluarga.

Kecamatan Tanasitolo khususnya di Desa Pakkana permintaan dari berbagai kecamatan setiap tahun mengalami peningkatan, hal ini yang menjadi salah satu alasan mengapa bahan sutera tumbuh dan berkembang di daerah ini. Oleh karena itu, Desa Pakkana dijadikan sebagai sebuah perkampungan sutera. Sebagian besar warga desa ini adalah para peternak ulat sutera sekaligus pengrajin tenun sutera. Di desa ini bisa ditemui kebun-kebun murbei sebagai lahan tumbuh bagi ulat-ulat penghasil kepompong yang nantinya menjadi bahan baku utama 'lippa sa'bbe' setelah sebelumnya dipintal menjadi benang. Tak jarang kebun-kebun tersebut berada di bawah rumah-rumah kayu penduduk. Suara "Tenun Bola-Bola, demikian masyarakat setempat menyebut alat tenun mereka yang dioperasikan oleh para pengrajin bisa di dengarkan di hampir seluruh wilayah Kecamatan Tanasitolo.

Desa Pakkana yang dari dahulu terkenal dengan industri pertenunan ATMB-nya sampai ke mancanegara menyebabkan daerah ini dijadikan sebagai ikon kota Sengkang karena itulah setiap usaha rumah tangga disini selalu mengupayakan modifikasi yang baru dari tenun kain sarung sutera. Oleh karena itu masyarakat desa Pakkana sangat membutuhkan pelatihan dan informasi baik tentang cara memodivikasi tenun sutra sehingga lebih bernilai tinggi (mahal) serta ingin mengetahui manajemen usaha sehingga dalam mengatur keuangan usaha sehingga mereka lebih bijak. Demikian juga dengan kondisi permodalan yang dimiliki kecil sehingga belum mampu memenuhi permintaan pasar secara maksimal. Cara pengelolaan usaha yang tidak konsisten dalam menjaga kualitas hasl industri pertenunan juga menjadi pemicu ketidaklancaran usaha utamanya bagi pengrajin ekonomi kreatif pemula. Satu hal yang perlu diketahui oleh permintaan pasar dari Negara Jepang terhadap sutera asal desa Pakkana yaitu mensyaratkan tidak boleh mengandung zat kimia utamanya Timbal $(\mathrm{Pb})$ karena itulah pengusaha sutera baik kecil maupun menengah berupaya mencari cara menghasilkan sutera yang tidak megandung Timbal $(\mathrm{Pb})$ dengan cara mengganti pewarna kimia dengan pewarna alami namun hal tersebut tidak dapat diterapkan oleh pengrajin ekonomi kreatif karena bahan pewarna kimia lebih cepat, mudah praktis penggunaannya.

Menengok ke masa yang lalu aktivitas masyarakat Wajo dalam mengelola persuteraan sudah dilakukan secara turun temurun baik diusahakan sebagai kegiatan sampingan maupun dikelola dalam skala industri rumah tangga. Hampir di setiap kecamatan di daerah ini ditemukan kegiatan persuteraan dimulai dari kegiatan proses hulu sampai ke hilir, kegiatan pemeliharaan ulat sutera hingga proses pemintalan menjadi benang yang kemudian ditenun menjadi selembar kain sutera. Usaha pemintalan sutera di Kabupaten Wajo berkembang dalam beberapa tingkatan bila dilihat dari operasionalnya yaitu menggunakan alat reeling dengan sistem manual, semi mekanis dan semi otomatis. Setidaknya terdapat 91 orang pengusaha yang menggeluti usaha ini dengan memperkerjakan 822 orang tenaga kerja. Dengan menggunakan alat mesin pemintal sebanyak 274 unit mereka mampu menghasilkan benang sutera mentah belum siap tenun sebanyak $6.389 \mathrm{~kg}$ per tahun dan selanjutnya benang sutera tersebut harus melalui proses penggintiran (twisting) lagi untuk mendapatkan benang sutera twist tenun. Kondisi inilah yang memberikan pilihan kepada pengusaha pertenunan sutera untuk menggunakan benang sutera dari daerah lain seperti dari Kabupaten Enrekang, Kabupaten Minahasa bahkan menggunakan benang sutera import yang sudah ada walaupun dengan harga yang lebih mahal demi memenuhi tuntutan kualitas permintaan pangsa pasar yang ada.

Memperhatikan kondisi industri pemintalan sutera ini pemerintah daerah Kabupaten Wajo merespon dengan mendatangkan peralatan laboratorium satu unit pada tahun 2005 dan alat mesin pemintalan otomatis sebanyak enam unit. Pada tahun 2008 yang saat ini telah dimanfaatkan dengan baik oleh pengusaha maupun pengrajin sutera dalam pengembangan ekonomi kreatif sehingga mampu memperbaiki dan meningkatkan mutu benang sutera yang dihasilkan. Peralatan lain 
yang diadakan pemerintah adalah alat mesin finishing sutera satu unit, namun belum dipergunakan secara optimal hal ini disebabkan karena pengoperasionalan mesin ini membutuhkan keahlian khusus dan biaya yang tidak sedikit sehingga dalam jangka waktu yang akan datang dibutuhkan pelatihan personal dan tambahan modal bagi pengusaha maupun pengrajin sutera dalam pengembangan ekonomi kreatif.

Usaha pertenunan sutera merupakan kegiatan yang paling banyak digeluti oleh pelaku persuteraan di Kabupaten Wajo, hal ini dilatar belakangi oleh produk kain sutera yang dihasilkan mempunyai nilai kegunaan yang dipadukan dengan nilai estetika budaya setempat. Perpaduan nilai tersebut menghasilkan karakteristik yang tersendiri mencirikan produk kain sutera khususnya sarung khas Sengkang. Tenun sutra tradisional Wajo sangat berpengaruh terhadap kehidupan masyarakat, salah satu faktor yang mempengaruhi kehidupan masyarakat Wajo terlihat dari produksi petani dan pengrajin tenun sutera. Selain di Kabupaten Wajo serta daerah lainnya di Sulawesi Selatan, pemasaran kain sutera masih dilakukan bebas artinya pihak konsumen dapat langsung membeli kain sutera kepada pengrajin ekonomi kreatif.

Dalam bahasa lokal (Bugis) sutera disebut dengan "Sabbe" dimana dalam proses pembuatan benang sutera menjadi kain sarung sutera masyarakat pada umumnya masih menggunakan peralatan tenun tradisional yaitu alat tenun gedongan dan ATBM dengan corak motif yang diproduksi seperti Gambar 1.

Kegiatan pengrajin sutera merupakan kegiatan yang melekat pada sebahagian masyarakat Bugis dan Makassar. Hal ini bisa dipahami bahwa adanya kepercayaan masyarakat Bugis dan Makassar bahwa seorang perempuan yang baik adalah perempuan yang bisa menenun (bisa menyelesaikan minimal satu lembar kain) maka ia sudah layak menikah. Kegiatan pengrajin ekonomi kreatif merupakan suatu bentuk ketrampilan perempuan Bugis yang menjadi kebanggaan masyarakat Bugis. Produksi tenunan Bugis Makassar memiliki kekhasan tersendiri dari segi warna, corak dan bahan bakunya.

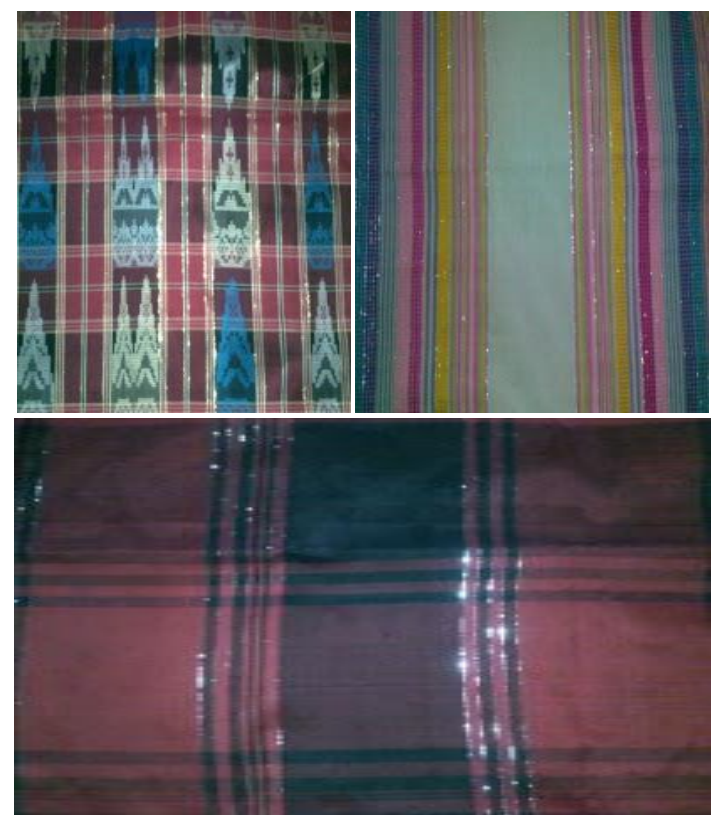

Gambar 1. Corak motif kain sutera

Pada tahun 1965 perkembangan sutera di Kabupaten Wajo dimulai dari seorang tokoh perempuan yang juga seorang bangsawan "Ranreng Tua" Wajo yaitu memperkenalkan alat tenun baru dari Thailand dan mampu memproduksi sutera asli (semacam Thai Silk) dalam skala besar, beliau mendatangkan seorang ahli pertenunan dari Thailand untuk mengajarkan penggunaan alat tenun tersebut kepada masyarakat setempat sekaligus menularkan sebagai ilmu pertenunan sehingga mampu menghasilkan produksi sutera yang berkualitas tinggi. Berawal dari prakarsa inilah sehingga memacu ketekunan dan membuka wawasan kreativitas masyarakat dan pengrajin yang lain untuk mengembangkan kegiatan persuteraan di Kabupaten Wajo.

Tahun 2008 industri pertenunan telah dikembangkan sebanyak 6.787 unit usaha, yang dapat menyerap tenaga kerja sekitar 19.544 orang dengan nilai investasi \pm Rp. 8.176 M dan hasil produksi \pm Rp. $34.432 \mathrm{M}$ produksi tersebut menggunakan ATBM dan pertenunan Gedongan. Guna pengembangan lebih lanjut hasil sutera di Kabupaten Wajo maka dibutuhkan perhatian instansi terkait dalam penyediaan bahan baku dan investasi ATBM, Input Teknologi Finishing, Batik Sutra, Pasar Grosir/Mini Mall, Deversifikasi, dan 
perluasan areal tanaman murbey makanan ulat sutera.

Pengrajin sutera dalam pengembangan ekonomi kreatif yang ada di Kabupaten Wajo adalah bagian dari masyarakat yang bersifat terbuka dan dinamis senantiasa memiliki keinginan pribadi (self interest) untuk berkembang. Gejala ini terlihat dari adanya beberapa pengusaha yang menggunakan pengrajin sutera dalam pengembangan ekonomi kreatif sebagai tenaga buruh. Namun disisi lain pengrajin sutera dalam mengembangkan ekonomi kreatif masih menggunakan tenaga kerja keluarga dan berproduksi atas dasar pesanan dari pembeli atau pedagang.

Basis etika moral orang Bugis pada umumnya memiliki nilai-nilai utama kebudayaan Bugis yang bertumpu pada budaya siri dan pesse, hal ini yang mendorong para pengusaha tenun untuk tetap membantu para pengrajin sutera dalam pengembangan ekonomi kreatif yang kurang memiliki modal untuk tetap membuat sarung sutera. Sistem ekonomi tenun secara perlahan mulai berubah dari bentuk produksi yang bersifat kultural menjadi produksi yang bersifat ekonomis dalam jaringan kultur struktur sosial yang tergantung satu dengan yang lainnya. Produksi yang sebelumnya hanya untuk keluarga dan adat (produk kultural) kini mulai berubah menjadi kepentingan sosial dan ekonomi. Kegiatan menenun ini bagi masyarakat Bugis mampu memberikan keuntungan yang sedikit untuk membantu pendapatan keluarga. Kondisi ini menyebabkan kegiatan menenun bukan hanya sebagai mata pencaharian sampingan untuk membantu ekonomi keluarga tetapi sebagai mata pencaharian pokok yang bisa membantu keluarga.

Bertahannya budaya menenun oleh pengrajin sutera dalam pengembangan ekonomi kreatif tidak terlepas dari kuatnya adat istiadat serta agama yang dianut sebagai falsafah hidup yang menjembatani zaman. Hasil kerajinan sutera yang dihasilkan oleh pengrajin dalam pengembangan ekonomi kreatif terlihat jelas pada tampilan hasil tenun. Corak dan warna merupakan bentuk yang menunjukkan identitas tertentu seperti tampilan kebangsawan maupun umur dari si pemakai. Makin rumit corak menandakan tingkat kebangsawan, hal ini berkaitan dengan warna si pemakai, makin gelap warna kain sutera maka diperuntukkan yang berusia tua.

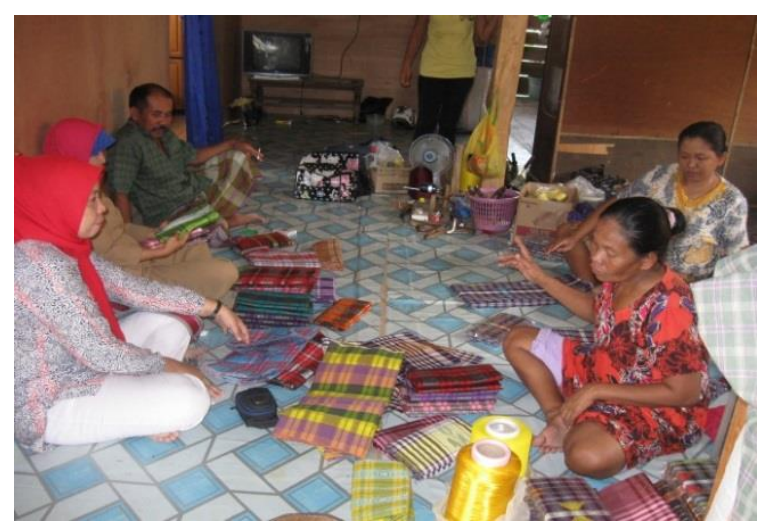

Gambar 2. Pengrajin kain sutera di Kabupaten Wajo

Dari uraian diatas nampak bahwa sistem ekonomi pada masyarakat Bugis menunjukkan bahwa kegiatan pengrajin sutera dalam pengembangan ekonomi kreatif tidak hanya terkait masalah kepentingan individu tetapi dengan aspek agama, sosial dan budaya.

\section{KESIMPULAN}

a. Karakteristik responden pengrajin sutera yakni (1) Jenis kelamin responden di desa Pakkanna semua wanita (2) usia responden antara 26-50 tahun menempati urutan tertinggi yakni $80 \%$, di bawah 25 tahun sebanyak 13,33\% dan diatas 50 tahun yakni $6,67 \%$; (3) tanggungan keluarga yang terbanyak memiliki yaitu tanggungan sebanyak 5-6 orang yaitu $36,67 \%$, (4) dari segi pengalaman responden, maka yang mempuyai pengalaman terbanyak yakni 20-25 tahun yaitu $13 \%$, dan (5) untuk tingkat pendidikan, rata-rata tingkat pendidikan sekolah menengah pertama (SMP) yaitu $50 \%$.

b. Pengembangan kerajinan sutera yang sudah dilakukan masih dalam taraf pengembangan motif desain yang sudah berbasis ekonomi kreatif dengan dikemas dengan motif modern sesuai dengan tingkat pesanan dari pedagang pengumpul dan konsumen yang langsung memesan. 